\title{
Review Article \\ Soil Health Management under Hill Agroecosystem of North East India
}

\author{
R. Saha, R. S. Chaudhary, and J. Somasundaram \\ Indian Institute of Soil Science, Indian Council of Agricultural Research, Nabibagh, Berasia Road, Bhopal, \\ Madhya Pradesh 462 038, India
}

Correspondence should be addressed to R. Saha, saharitesh74@rediffmail.com

Received 2 December 2011; Revised 2 February 2012; Accepted 3 February 2012

Academic Editor: María Cruz Díaz Álvarez

Copyright ( 92012 R. Saha et al. This is an open access article distributed under the Creative Commons Attribution License, which permits unrestricted use, distribution, and reproduction in any medium, provided the original work is properly cited.

The deterioration of soil quality/health is the combined result of soil fertility, biological degradation (decline of organic matter, biomass C, decrease in activity and diversity of soil fauna), increase in erodibility, acidity, and salinity, and exposure of compact subsoil of poor physicochemical properties. Northeast India is characterized by high soil acidity/Al ${ }^{+3}$ toxicity, heavy soil, and carbon loss, severe water scarcity during most parts of year though it is known as high rainfall area. The extent of soil and nutrient transfer, causing environmental degradation in North eastern India, has been estimated to be about 601 million tones of soil, and $685.8,99.8,511.1,22.6,14.0,57.1$, and 43.0 thousand tones of N, P, K, Mn, Zn, Ca, and Mg, respectively. Excessive deforestation coupled with shifting cultivation practices have resulted in tremendous soil loss $(200 \mathrm{t} / \mathrm{ha} / \mathrm{yr})$, poor soil physical health in this region. Studies on soil erodibility characteristics under various land use systems in Northeastern Hill (NEH) Region depicted that shifting cultivation had the highest erosion ratio (12.46) and soil loss (30.2-170.2 t/ha/yr), followed by conventional agriculture system (10.42 and 5.10-68.20 t/ha/yr, resp.). The challenge before us is to maintain equilibrium between resources and their use to have a stable ecosystem. Agroforestry systems like agri-horti-silvi-pastoral system performed better over shifting cultivation in terms of improvement in soil organic carbon; SOC (44.8\%), mean weight diameter; MWD (29.4\%), dispersion ratio (52.9\%), soil loss $(99.3 \%)$, soil erosion ratio $(45.9 \%)$, and in-situ soil moisture conservation $(20.6 \%)$ under the high rainfall, moderate to steep slopes, and shallow soil depth conditions. Multipurpose trees (MPTs) also played an important role on soil rejuvenation. Michelia oblonga is reported to be a better choice as bioameliorant for these soils as continuous leaf litter and root exudates improved soil physical behaviour and SOC considerably. Considering the present level of resource degradation, some resource conservation techniques like zero tillage/minimum tillage, hedge crop, mulching, cover crop need due attention for building up of organic matter status for sustaining soil health.

\section{Introduction}

Soil degradation has raised some serious debate, and it is an important issue in the modern era. It refers to the decline in soil's inherent capacity to produce economic goods and perform ecologic functions. It is the net result of dynamic soil degradative and restorative processes regulated by natural and anthropogenic factors. The degree of soil degradation depends on soil's susceptibility to degradative processes, land use, the duration of degradative land use, and the management. Soil and water degradation are also related to overall environmental quality, of which water pollution and the "greenhouse effect" are two major concerns of global significance. Recent global concerns over increased atmospheric $\mathrm{CO}_{2}$, which can potentially alter the earth's climate systems, have resulted in raising interest in studying Soil organic matter (SOM) dynamics and carbon (SOC) sequestration capacity in various ecosystems [1]. Soils represent an important terrestrial stock of $\mathrm{C}$ and approximately two to three times as much as terrestrial vegetation and atmosphere, respectively, and the $\mathrm{C}$ in the SOM of agricultural land is composed of dominant terrestrial C stock. Soil quality is the capacity of a soil to function within ecosystem boundaries to sustain biological productivity, maintain environmental quality, and promote plant and animal health and thus has a profound effect on the health and productivity of a given ecosystem and the environment related to it.

The North Eastern parts of India, comprising the states of Arunachal Pradesh, Assam, Manipur, Meghalaya, Mizoram, 
TABLE 1: Trends of forest loss/gain $\left(\mathrm{km}^{2}\right)$ in NEH region.

\begin{tabular}{|c|c|c|c|c|c|c|c|}
\hline \multirow[b]{2}{*}{ States } & \multicolumn{3}{|c|}{1999 Assessment } & \multicolumn{3}{|c|}{2001 Assessment } & \multirow[b]{2}{*}{ Net difference } \\
\hline & $\begin{array}{c}\text { Dense forest } \\
\text { cover }\end{array}$ & $\begin{array}{c}\text { Open forest } \\
\text { cover }\end{array}$ & $\begin{array}{c}\text { Total forest } \\
\text { cover }\end{array}$ & $\begin{array}{c}\text { Dense forest } \\
\text { cover }\end{array}$ & $\begin{array}{c}\text { Open forest } \\
\text { cover }\end{array}$ & $\begin{array}{c}\text { Total forest } \\
\text { cover }\end{array}$ & \\
\hline Arunachal Pradesh & 57,756 & 11,091 & 68,847 & 53,932 & 14,113 & 68,045 & $(-) 802$ \\
\hline *Assam & 15,548 & 8,276 & 23,824 & 14,517 & 9,171 & 23,688 & $(-) 136$ \\
\hline Manipur & 5,936 & 11,448 & 17,384 & 5,710 & 11,216 & 16,926 & $(-) 458$ \\
\hline Meghalaya & 5,925 & 9,708 & 15,633 & 5,681 & 9,903 & 15,584 & $(-) 49$ \\
\hline Mizoram & 3,786 & 14,552 & 18,338 & 8,936 & 8,558 & 17,494 & $(-) 844$ \\
\hline Nagaland & 5,137 & 9,027 & 14,164 & 5,393 & 7,952 & 13,345 & $(-) 819$ \\
\hline Sikkim & 2,363 & 755 & 3,118 & 2,391 & 802 & 3,193 & 75 \\
\hline Tripura & 2,228 & 3,517 & 5,745 & 3,463 & 3,602 & 7,065 & 1320 \\
\hline **Total & 83,131 & 60,098 & $1,43,229$ & 85,506 & 56,146 & $1,41,652$ & $(-) 1577$ \\
\hline
\end{tabular}

*Data for Assam is during the assessment year of 1997-1999 and **total reports only for NEH region. Source: [4].

Nagaland, Sikkim, and Tripura, lies between $22^{\circ} 05^{\prime}$ and $29^{\circ} 30^{\prime} \mathrm{N}$ latitudes and $87^{\circ} 55^{\prime}$ and $97^{\circ} 24^{\prime} \mathrm{E}$ longitudes. The region is characterised by diverse agroclimatic and geographical situations. About 54.1 per cent of the total geographical area is under forests, 16.6 per cent under crops, and the rest either under nonagricultural uses or uncultivated land. The low area under agricultural crops is due to natural corollary of the physiographic features of the region, as major chunk of the land has more than 15 per cent slope, undulating topography, highly eroded and degraded soils, and inaccessible terrain. Continuous dilution of the forest cover in the region due to shifting cultivation, firewood, and timber collection is posing the most crucial problem resulting in poor soil health and environmental degradation in the hills.

\section{Shifting Cultivation}

Shifting cultivation, also known as Jhum cultivation, is the most traditional and dominant land use system in this region. On an average, $3,869 \mathrm{~km}^{2}$ area is put under shifting cultivation every year. Shifting cultivation in its more traditional and cultural integrated form is an ecological and economically viable system of agriculture as long as population densities are low and jhum cycles are long enough to maintain soil fertility. The system involves cultivation of crops in steep slopes. Land is cleared by cutting of forests, bushes, and so forth up to the stump level, leaving the cut materials for drying and finally burning to make the land ready for sowing of seeds of different crops before the onset of rains. The cultivation is confined to a village boundary and often after two or three years, the cultivated area is abandoned and a new site is selected to repeat the process. The shifting cultivation became unsustainable today primarily due to the increase in population that led to increase in food demand. Jhuming cycle in the same land, which extended to 20-30 years in earlier days, has now been reduced to 3-6 years [2]. Land degradation in the region is $36.64 \%$ of the total geographical area, which is almost double than the national average of $20.17 \%$ [3]. The problem of land degradation is much serious in the states like Manipur, Nagaland, and Sikkim, where more than $50 \%$ of total geographical area is defined as wastelands. Of various degradation types, water erosion, reduced infiltration, acidification, nutrient leaching, burning of vegetation, decline in vegetative cover, and biodiversity are important in context to the NE region.

\section{Effect of Shifting Cultivation}

3.1. Change in Forest Cover. The total forest cover in the region is $1,41,652 \mathrm{~km}^{2}$, which is about $54.1 \%$ of the geographic area as against the national average of $19.39 \%$ [4]. Manipur and Meghalaya have dense forest cover of 25.57 and $25.33 \%$, respectively (Table 1 ). Similarly for Nagaland, Sikkim, Tripura, and Mizoram, the dense forest cover is 32.53, 33.70, 33.02 and 42.39\%, respectively. Among seven sisters of NEH, Arunachal Pradesh is the only state, which has the dense forest cover of $64.0 \%$. Since shifting cultivation is still practiced in the region, and every year dense forest is converted into jhum fields, there is drastic reduction in dense forest cover (canopy density $>40 \%$ ) in most of the states.

3.2. Effect of Burning on Soil Fertility. The burning process related to shifting cultivation practices has tremendous effect on soil ecosystem. The impact of fire on ecosystem is profound and its consequences are dependent on intensity and frequency of fire, proportion of biomass burned, the time of monsoon setting, and total annual precipitation. The extent to which organic matter is transformed into ash depends on a number of factors viz intensity and duration of fire, fuel load, moisture content in the fuel, weather, and topography. Burning of above-ground vegetation showed an increase in $\mathrm{pH}$ and cations and a decrease in carbon and nitrogen contents in the surface soil [5]. Quick release of nutrients especially cations after burning has been reported by Kellman et al. [6]. The organic carbon content of soil decreased drastically after burning because of oxidation loss. Rise in $\mathrm{pH}$, temperature, and bases of the soil might have increased the microbial activity after burning which in 
TABLE 2: Effect of various MPTs on soil physical properties.

\begin{tabular}{lccccc}
\hline MPTs & Organic $\mathrm{C}\left(\mathrm{g} \mathrm{kg}^{-1}\right)$ & Aggregate stability & Available water $\left(\mathrm{m}^{3} \mathrm{~m}^{-3}\right)$ & Infiltration rate $\left(\mathrm{mm} \mathrm{h}^{-1}\right)$ & Erosion ratio \\
\hline Pinus kesiya & 35.4 & 75.6 & 0.220 & 8.04 & 0.20 \\
Alnus nepalensis & 32.2 & 72.1 & 0.201 & 7.28 & 0.23 \\
Parkia roxburghii & 23.1 & 63.4 & 0.192 & 4.85 & 0.30 \\
Michelia oblonga & 33.6 & 73.2 & 0.210 & 6.10 & 0.22 \\
Gmelina arboria & 28.6 & 67.9 & 0.183 & 5.36 & 0.24 \\
Control (No tree) & 15.6 & 56.8 & 0.151 & 3.84 & 0.39 \\
\hline
\end{tabular}

Source: [16].

turn resulted in accelerating mineralization of organic $\mathrm{N}$ to inorganic forms $[7,8]$.

3.3. Soil Erosion and Nutrient Loss. Soil erosion under shifting cultivation is highly erratic from year to year depending on rainfall characteristics. Studies on steep slopes (44-53\%) have indicated the soil loss to the tune of $40.9 \mathrm{t} / \mathrm{ha}$ and the corresponding nutrient losses per hectare are $702.9 \mathrm{~kg}$ of organic carbon, $63.5 \mathrm{~kg}$ of P and $5.9 \mathrm{~kg}$ of $\mathrm{K}$ [9]. The soil loss from hill slopes $(60-79 \%)$ under first year, second year, and abandoned jhum was estimated to be 147,170 , and $30 \mathrm{t} / \mathrm{ha} / \mathrm{yr}$ [10]. In general, tolerable soil loss $(T)$ value is $11.2 \mathrm{Mg} / \mathrm{ha} / \mathrm{yr}$ (5.0 t/ac/yr) while it is between 5.0 and $12.5 \mathrm{Mg} / \mathrm{ha} / \mathrm{yr}(2.2$ and $5.6 \mathrm{t} / \mathrm{ac} / \mathrm{yr}$ ) in North West Himalayas [11]. During first few years of clearing, carbon and nitrogen levels decrease rapidly. According to one estimate annual loss of top soil, N, $\mathrm{P}$ and $\mathrm{K}$ due to shifting cultivation is $88346,10669,0.372$, and 6051 thousand tones in the region [12]. Singh et al. [13] reported nutrient loss to the tune of 6.0 million tones of organic carbon, 9.7 tones of available $\mathrm{P}$, and 5690 tones of $\mathrm{K}$ from the NEH region. Nutrient losses from the jhum field through runoff and percolation are rather heavy during cropping.

\section{Long-Term Strategies for Resource Conservation and Improvement in Soil Health}

Nearly $37.1 \%$ of the total geographical area in Northeast India is under the threat of land degradation, where erosion is a major land degradative process. With the great concern of poor soil health and severe land degradation, there is a need of viable option for ecorestoration and maintenance of soil resources which could sustain long-term soil productivity and improve food security of the poor tribal farmers of northeast India under the humid subtropical climate of the north-eastern Himalayan region. Three broad strategies, suitable for different land situation, elevation, and topography prevailing in this region, are discussed here.

4.1. Multipurpose Trees (MPTs). The multipurpose tree species (MPTs) form an integral component of different agroforestry interventions in crop sustainability. The MPTs, besides furnishing the multiple outputs like fuel, fodder, timber, and other miscellaneous products, help in improvement of soil health and other ecological conditions. Farmers of the region integrate various tree species in different land use in the region; however, priority species vary from state to state and even from place to place within a state based on ethnic diversity and food habits of the tribal communities. In the region, as many as 40 promising species are cultivated in tropical and subtropical region, and 30 in temperate zone of the region in different farming systems. Besides, 28 bamboo species and 2 genera of cane also find a place in various agroforestry programmes. Tree density ha $\mathrm{ha}^{-1}$ is also a crucial factor on sloppy lands. In general, optimum tree density in case of agri-horticulture system is 400 trees/ha, while in agri-silviculture, it is 200 plants/ha so as to minimize the effect of shade and biochemical interactions on growth and production of agricultural crops $[14,15]$.

Long-term effect of various multipurpose tree species on soil physical behaviour has been studied [16]. Multipurpose tree species with greater surface cover, constant leaf litter fall, and extensive root system increased soil organic $\mathrm{C}$ by $96.2 \%$, porosity by $10.9 \%$, aggregate stability by $24.0 \%$, and available soil moisture by $33.2 \%$ and simultaneously reduced bulk density and erosion ratio by 15.9 and $39.5 \%$, respectively (Table 2). Among the tree species tested, P. kesiya, M. oblonga and Alnus nepalensis were found suitable as bioameliorant in hilly terrain of northeast India in terms of organic matter buildup through presence of leaf litter, better soil aggregation, transmissivity, and infiltrability through extensive root system, improved soil conservation through constant surface cover with leaf biomass. Such improvement in soil hydrophysical properties in tree-based system has a direct bearing on long-term sustainability, productivity, and soil quality in hilly ecosystem.

4.2. Agroforestry Interventions in Degraded Lands. The region has a very high rate of land degradation. In this region, 7.85 million ha area is degraded which need rehabilitation through various agroforestry models [3]. Agroforestry system (AFS) has today become an established approach of integrated land management system not only for renewable resource production but also for ecological consideration. It represents the integration of agriculture and forestry to increase the productivity and sustainability of farming system.

4.2.1. Soil Fertility Buildup. Study revealed that organic carbon, available $\mathrm{P}$, and exchangeable cations contents in surface soil ranged in between $2.0-2.5 \%, 10.4-13.2 \mathrm{ppm}$, and 5.9$8.4 \mathrm{cmol}\left(\mathrm{p}^{+}\right) \mathrm{kg}^{-1}$, respectively, under jackfruit-based AFS, 
TABLE 3: Effect of agroforestry systems on soil properties.

\begin{tabular}{|c|c|c|c|c|c|c|}
\hline \multirow[b]{2}{*}{ Soil properties } & \multicolumn{6}{|c|}{ Agroforestry systems } \\
\hline & Agrisilviculture & $\begin{array}{c}\text { Agrihorti } \\
\text { culture (khasi } \\
\text { mandarin }+ \\
\text { crops) }\end{array}$ & $\begin{array}{c}\text { Agrihorti } \\
\text { culture (Assam } \\
\text { lemon }+ \\
\text { crops) }\end{array}$ & $\begin{array}{c}\text { Silvihorti } \\
\text { pastoral (Alder } \\
+ \text { pine apple }+ \\
\text { fodder grass) }\end{array}$ & $\begin{array}{l}\text { Multistoried } \\
\text { AFS (Alder + } \\
\text { tea + black } \\
\text { pepper }+ \\
\text { crops) }\end{array}$ & Natural forest \\
\hline $\mathrm{pH}$ & 4.65 & 4.62 & 4.80 & 4.25 & 4.61 & 4.62 \\
\hline Organic C (\%) & 1.62 & 1.55 & 2.02 & 2.19 & 1.91 & 1.92 \\
\hline $\begin{array}{l}\text { Exchangeable Ca } \\
{\left[\mathrm{cmol}\left(\mathrm{p}^{+}\right) \mathrm{kg}^{-1}\right]}\end{array}$ & 0.40 & 0.86 & 0.74 & 0.31 & 0.65 & 0.26 \\
\hline $\begin{array}{l}\text { Exchangeable Mg } \\
{\left[\mathrm{cmol}\left(\mathrm{p}^{+}\right) \mathrm{kg}^{-1}\right]}\end{array}$ & 0.75 & 0.51 & 0.33 & 0.48 & 0.71 & 0.16 \\
\hline $\begin{array}{l}\text { Exchangeable K } \\
{\left[\mathrm{cmol}\left(\mathrm{p}^{+}\right) \mathrm{kg}^{-1}\right]}\end{array}$ & 0.232 & 0.244 & 0.249 & 0.238 & 0.201 & 0.169 \\
\hline $\begin{array}{l}\text { Exchangeable } \mathrm{Na} \\
{\left[\mathrm{cmol}\left(\mathrm{p}^{+}\right) \mathrm{kg}^{-1}\right]}\end{array}$ & 0.201 & 0.220 & 0.194 & 0.195 & 0.197 & 0.196 \\
\hline $\begin{array}{l}\text { Exchangeable Al } \\
{\left[\mathrm{cmol}\left(\mathrm{p}^{+}\right) \mathrm{kg}^{-1}\right]}\end{array}$ & 2.65 & 2.70 & 2.20 & 3.15 & 2.05 & 2.20 \\
\hline Available N (ppm) & 190.1 & 180.8 & 203.6 & 199.4 & 216.9 & 167.2 \\
\hline Available P (ppm) & 2.75 & 4.10 & 5.36 & 0.94 & 3.36 & 0.63 \\
\hline Available Fe (ppm) & 8.9 & 10.4 & 12.8 & 10.9 & 13.9 & 7.3 \\
\hline Available Mn (ppm) & 0.58 & 0.92 & 0.79 & 0.83 & 1.04 & 0.04 \\
\hline Available Zn (ppm) & 0.08 & 0.05 & 0.07 & 0.006 & 0.08 & 0.025 \\
\hline Available Cu (ppm) & 0.21 & 0.23 & 0.37 & 0.30 & 0.27 & 0.10 \\
\hline
\end{tabular}

Source: [18].

while $1.5-1.8 \%$ organic carbon, $3.8-6.7 \mathrm{ppm}$ available $\mathrm{P}$, and $3.9-5.9 \mathrm{cmol}\left(\mathrm{p}^{+}\right) \mathrm{kg}^{-1}$ total cations were found under arecanut/khasi mandarin-based AFS [17].

In an another study, long-term effect of agri-horticulture (comprising Khasi mandarin + agricultural crops, and Assam lemon + agricultural crops), agri-silviculture (multipurpose tree species + annual agricultural crops), silvi-horti-pastoral (alder + pine apple + fodder grasses), and multistoried AFS (alder + tea + black pepper + annual agricultural crops between the tree rows) on soil properties and fertility status was evaluated in acid Alfisol of Meghalaya compared with natural forest as a control. In all the AFS, significant (1.17-1.65 fold) increase in organic carbon was found as compared to initial status, the maximum contribution being by silvi-horti-pastoral AFS. The same system also registered 43.2\% higher exchangeable $\mathrm{Al}$ compared to natural forest and consequently a maximum decrease of 0.50 units in $\mathrm{pH}$ (Table 3). The exchangeable $\mathrm{Ca}, \mathrm{Mg}, \mathrm{Na}, \mathrm{K}$, and $\mathrm{Al}$ and available $\mathrm{N}, \mathrm{P}$, and $\mathrm{K}$ content were higher in all the systems compared to natural forest and the content of these nutrients decreased with increasing soil depth [18].

In a study under Farming System Research Project (FSRP) carried out at ICAR Research Complex, Barapani, effect of various AFS like silvi-pastoral, silvi-horticulture, agri-horti-silvipastoral has been evaluated [19] after 17 years of their adoption on soil fertility indices (Table 4). The natural fallow and abandoned jhum land at Umiam were taken for comparison. Organic carbon content increased in all the AFS including natural fallow, however, the quantity largely depended on the nature of vegetation in different systems. Adoption of different cropping pattern in various AFS markedly influenced the exchangeable $\mathrm{Ca}, \mathrm{Mg}$, and $\mathrm{K}$ content in the soil. Maximum accumulation of these cations was recorded under agri-horti-silvipastoral and silvihorticulture AFS followed by natural fallow and silvi-pastoral systems. Accumulation of exchangeable $\mathrm{K}$ was maximum in silvi-horticulture followed by agri-horti-silvipastoral. The available $\mathrm{N}, \mathrm{P}$, and $\mathrm{S}$ were higher in agri-horti-silvipastoral and silvi-horticulture compared to natural fallow and silvipastoral AFS.

4.2.2. Soil Physical Health. Effect of various land use systems on soil physical properties shown in Table 5 indicated that the maximum reduction in bulk density over shifting cultivation was recorded in forest $(17.6 \%)$ followed by agrihorti-silvi-pastoral (14.3\%), livestock based (13.4\%), natural fallow, and agriculture system (12.6\%). Higher percentage of macroaggregates (54.5\%), organic C content $(2.95 \%)$, and biotic activity were also observed in forest ecosystem. Soil biota influences soil properties through formation of stable aggregates, development of organomineral complexes by improving macroporosity and continuity of pores from surface to the subsoil which ultimately increase the water transmission and reduce run-off. Higher transmission and storage pore volume coupled with lower value of residual pores associated with modified land use systems as compared to shifting-cultivated plots was thus an indication of maintaining the pore geometry of the soil under these systems. 
TABLE 4: Effect of different land use systems developed under FSRP, Meghalaya on soil properties.

\begin{tabular}{|c|c|c|c|c|c|}
\hline \multirow{2}{*}{ Characteristics } & \multicolumn{5}{|c|}{ Agroforestry systems } \\
\hline & Natural fallow & $\begin{array}{l}\text { Abandoned jhum } \\
\text { land }\end{array}$ & Silvipastoral & $\begin{array}{l}\text { Agri-horti- } \\
\text { silvipastoral }\end{array}$ & $\begin{array}{l}\text { Silvihorti- } \\
\text { culture }\end{array}$ \\
\hline $\mathrm{pH}$ & $4.99(4.90)$ & $4.76(5.20)$ & $4.52(5.10)$ & $4.92(4.90)$ & $4.91(4.90)$ \\
\hline Organic C (\%) & $2.94(1.85)$ & $3.42(1.90)$ & $2.61(1.80)$ & $2.97(1.82)$ & $2.97(1.80)$ \\
\hline $\begin{array}{l}\text { Exchangeable Ca } \\
{\left[\mathrm{cmol}\left(\mathrm{p}^{+}\right) \mathrm{kg}^{-1}\right]}\end{array}$ & $1.96(1.15)$ & $1.57(1.16)$ & $1.25(1.10)$ & $2.11(1.20)$ & $2.00(1.20)$ \\
\hline $\begin{array}{l}\text { Exchangeable Mg } \\
{\left[\mathrm{cmol}\left(\mathrm{p}^{+}\right) \mathrm{kg}^{-1}\right]}\end{array}$ & $0.55(1.15)$ & $0.38(1.16)$ & $0.43(1.20)$ & $1.45(1.20)$ & $0.85(0.60)$ \\
\hline $\begin{array}{l}\text { Exchangeable Al } \\
{\left[\mathrm{cmol}\left(\mathrm{p}^{+}\right) \mathrm{kg}^{-1}\right]}\end{array}$ & 0.88 & 1.30 & 1.56 & 0.90 & 0.90 \\
\hline Available N (ppm) & 179.2 & 251.1 & 214.5 & 220.3 & 210.9 \\
\hline Available P (ppm) & 1.9 & 2.0 & 2.1 & 16.6 & 12.9 \\
\hline Available K (ppm) & 175.6 & 130.8 & 98.0 & 162.7 & 265.0 \\
\hline Available S (ppm) & 14.5 & 14.8 & 10.4 & 19.9 & 12.9 \\
\hline
\end{tabular}

Figures in parentheses indicate the initial values at the start of the project. Source: [19].

TABLE 5: Effect of different land use systems developed under FSRP, Meghalaya on soil physical properties.

\begin{tabular}{|c|c|c|c|c|c|c|}
\hline \multirow{2}{*}{ Soil properties } & \multicolumn{6}{|c|}{ Land use systems } \\
\hline & Agriculture & $\begin{array}{l}\text { Agri-horti- } \\
\text { silvipastoral }\end{array}$ & Forestry & Livestock based & Natural fallow & Shifting cultivation \\
\hline Bulk density $\left(\mathrm{Mg} \mathrm{m}^{-3}\right)$ & 1.04 & 1.02 & 0.98 & 1.03 & 1.04 & 1.19 \\
\hline Total Porosity (\%) & 59.67 & 60.47 & 62.02 & 60.08 & 66.23 & 53.88 \\
\hline Macroaggregates $(>0.25 \mathrm{~mm})$ & 21.72 & 54.19 & 54.47 & 50.02 & 50.53 & 18.17 \\
\hline Microaggregates (<0.25 mm) & 47.85 & 23.23 & 23.81 & 22.80 & 21.90 & 42.34 \\
\hline $\operatorname{MWD}(\mathrm{mm})$ & 2.76 & 2.99 & 3.16 & 2.85 & 2.93 & 2.31 \\
\hline Available water $\left(\mathrm{m}^{3} \mathrm{~m}^{-3}\right)$ & 0.210 & 0.222 & 0.231 & 0.220 & 0.233 & 0.169 \\
\hline Hydraulic Conductivity $\left(\mathrm{cm} \mathrm{hr}^{-1}\right)$ & 2.74 & 4.72 & 5.47 & 2.95 & 6.66 & 2.09 \\
\hline
\end{tabular}

Source: [20].

The better soil aggregation under natural forest, multistoried AFS, and silvihortipastoral systems maintaining intensive vegetative cover throughout the year could be ascribed to the effect of higher percentage of organic matter, clay content, and high amount of $\mathrm{Al}$ and $\mathrm{Fe}$ oxides in soil.

4.2.3. Soil and Water Conservation. Some of the potential farming systems such as agriculture on bench terraces, horticulture, and agri-horti-silvipastoral systems have been evaluated [21] at the experimental watershed of ICAR Research Complex at Barapani for long-term runoff, soil and nutrient losses, production behaviour, biotic and abiotic changes, and so on. The data indicated that mixed land use systems with appropriate soil conservation measures, namely, bench terraces, contour trenches, and so forth, were the most effective in retaining $90-100 \%$ annual rainfall and simulated the effects of natural forest. The contributions to stream flow in the watersheds having substantial area under natural forest is primarily by subsurface flow (base flow). The watersheds having continuous stream flow characteristics generated base flow to the extent of $70-90 \%$ of its total water yields. As expected, the watershed treated with jhum (shifting) cultivation yielded the highest peak runoff while the one left undisturbed with natural vegetation gave the minimum peak runoff. The results revealed that agroforestry and other mixed land use systems most effectively conserved moisture and substantially reduced peak runoff (Tables 6(a) and 6(b)). The low erosion ratio values in silvi-horti-pastoral and multistoried AFS (3.07 and 3.06, resp.) showed that these systems were the most suitable for soil and water conservation in hilly ecosystem [22]. This could be ascribed to the effect of heavy litter fall, which might have increased the cohesiveness in the soil system after decomposition and also binds the soil tightly in lower horizons by their deep root systems.

4.2.4. Soil C Sequestration Potential. Assessment of soil quality is an invaluable tool in determining the sustainability and environmental impact of agricultural ecosystems. Soil quality under different agroecosystems using soil organic carbon (SOC) and soil microbial C (SMBC) as soil quality indicators suggests that the shifting cultivated areas had the lowest SMBC value of $192 \mathrm{mg} / \mathrm{kg}$ while soil under Michelia oblonga plantation had the significantly $(P<0.05)$ highest 
TABle 6: (a) Pretreatment (year) precipitation, storm flow, peak flow rate in different land use systems. (b) posttreatment water yield, base flow, and peak flow in different land use systems (average of nine years).

(a)

\begin{tabular}{|c|c|c|c|c|c|c|}
\hline Land use system & $\begin{array}{l}\text { Precipitation } \\
\quad(\mathrm{mm})\end{array}$ & $\begin{array}{c}\text { Threshold } \\
\text { rainfall (mm) }\end{array}$ & $\begin{array}{l}\text { Total water } \\
\text { yield }(\mathrm{mm})\end{array}$ & $\begin{array}{l}\text { Total water yield } \\
\text { (\% of rainfall) }\end{array}$ & $\begin{array}{c}\text { Surface } \\
\text { runoff }(\mathrm{mm})\end{array}$ & $\begin{array}{l}\text { Peak flow } \\
\left(\mathrm{mm} \mathrm{hr}^{-1}\right)\end{array}$ \\
\hline Dairy based farming & 2249.30 & 363.20 & 27.21 & 1.20 & 27.21 & 3909 \\
\hline Forestry block & 2249.30 & 399.90 & 655.21 & 29.12 & 54.30 & 16.94 \\
\hline Agroforestry & 2249.30 & 533.70 & 32.55 & 1.45 & 9.90 & 6.17 \\
\hline Agropastoral & 2249.30 & 364.30 & 25.50 & 1.13 & 25.50 & 31.86 \\
\hline Agrohortisilvipastoral & 2249.30 & 348.60 & 4.10 & 0.18 & 4.10 & 10.45 \\
\hline Natural fallow & 2249.30 & 541.70 & 2.87 & 0.13 & 2.87 & 13.65 \\
\hline Shifting cultivation & 2249.30 & 1634.5 & 15.88 & 0.70 & 15.88 & 35.30 \\
\hline \multicolumn{7}{|c|}{ (b) } \\
\hline Land use systems & \multicolumn{2}{|c|}{$\begin{array}{l}\text { Annual water yield range } \\
(\mathrm{mm})\end{array}$} & $\begin{array}{l}\text { Mean water yield } \\
(\mathrm{mm})\end{array}$ & $\begin{array}{l}\text { Mean water yiel } \\
\text { of annual rain }\end{array}$ & \multicolumn{2}{|c|}{$\begin{array}{c}\text { Maximum peak flow } \\
\left(\mathrm{mm} \mathrm{hr}^{-1}\right)\end{array}$} \\
\hline Dairy based farming & \multicolumn{2}{|c|}{$0-66.699$} & 9.56 & 0.37 & \multicolumn{2}{|c|}{7.81} \\
\hline Forestry block & \multicolumn{2}{|c|}{$67.42-1013.88$} & 371.90 & 4.73 & \multicolumn{2}{|c|}{13.54} \\
\hline Agroforestry & \multicolumn{2}{|c|}{$39.31-648.26$} & 241.14 & 9.55 & \multicolumn{2}{|c|}{12.87} \\
\hline Agropastoral & \multicolumn{2}{|c|}{$0.60-62.49$} & 12.47 & 0.69 & \multicolumn{2}{|c|}{20.71} \\
\hline Agrohortisilvipastoral & \multicolumn{2}{|c|}{$0.24-121.91$} & 28.98 & 1.14 & \multicolumn{2}{|c|}{12.07} \\
\hline Natural fallow & \multicolumn{2}{|c|}{$0-51.39$} & 11.77 & 0.46 & \multicolumn{2}{|c|}{4.49} \\
\hline Shifting cultivation & \multicolumn{2}{|c|}{$0-517.72$} & 102.94 & 4.07 & \multicolumn{2}{|c|}{86.10} \\
\hline
\end{tabular}

Source: [21].

TABLE 7: Growth, litter production, fine root biomass of promising MPTs in humid tropics, and their contribution on SOC content.

\begin{tabular}{|c|c|c|c|c|}
\hline MPT & $\begin{array}{l}\text { Annual litter production } \\
\qquad\left(\mathrm{g} \mathrm{m}^{-2}\right)\end{array}$ & $\begin{array}{c}\text { Time required for } \\
\text { decomposition (days) }\end{array}$ & $\begin{array}{c}\text { Total fine root } \\
\text { biomass }\left(\mathrm{g} \mathrm{m}^{-2}\right)\end{array}$ & Organic C $\left(\mathrm{g} \mathrm{kg}^{-1}\right)$ \\
\hline P. kesiya & 621.5 & 718 & 496.75 & 35.4 \\
\hline A. nepalensis & 473.75 & 350 & 435.50 & 32.2 \\
\hline P. roxburghii & 341.75 & 385 & 415.50 & 23.1 \\
\hline M. oblonga & 512.25 & 390 & 462.00 & 33.6 \\
\hline G. arboria & 431.75 & 360 & 419.00 & 28.6 \\
\hline
\end{tabular}

Source: [16].

value of $478 \mathrm{mg} / \mathrm{kg}$. The proportion of $\mathrm{SMBC}$ to total soil organic carbon (SOC) was in the range of 0.76 to $1.96 \%$ across all the systems. Multipurpose tree species like P. kesiya, A. nepalensis, $P$. roxburghii, M. oblonga, and G. arboria with greater surface cover, constant leaf litter fall, and extensive root systems increased soil organic carbon by 96.2\% (Table 7), helped with better aggregate stability by $24.0 \%$, improved available soil moisture by $33.2 \%$, and in turn reduced soil erosion by $39.5 \%$ [16, 23]. Similarly, a comparative study on the effect of various MPTs on soil organic carbon pool (Table 8) showed a concomitant rise in SOC in soils under MPTs and a subsequent decline in soils of open space over 4-16 years. Maximum rise in SOC was noticed in soils of $A$. indica $\left(28.6 \mathrm{Mg} / \mathrm{hm}^{2}\right)$ followed by A. Aurculiformisi (21.9 Mg/hm²), G. arborea $\left(21.8 \mathrm{Mg} / \mathrm{hm}^{2}\right)$, M. Champaca $\left(16.7 \mathrm{Mg} / \mathrm{hm}^{2}\right)$, and so forth. The minimum rise in SOC was noted in soils under T. grandis. So an increase of SOC was noted from $3.8 \mathrm{Mg} / \mathrm{hm}^{2}$ in soils of open space to $19.5 \mathrm{Mg} / \mathrm{hm}^{2}$ in that under MPTs after 16 years. The comparatively high humin carbon present in soils under A. auriculiformis, L. leucocephala, and G. Arborea indicated the enhanced storage of organic carbon pool in agroforestry systems [24]. Swamy et al. [25] estimated that a six-year-old $G$. arborea, based agri-sivicultural systems in India sequestered $31.4 \mathrm{Mg} \mathrm{hm}^{-2}$ carbon.

\subsection{Resource Conservation Techniques}

4.3.1. Conservation Tillage. Conservation tillage are system of managing crop residue on the soil surface with minimum disturbance. The stubble mulch or reduced tillage/minimum tillage, no tillage and direct drill are components of conservation tillage. The objectives are (i) to leave enough plant residue on the soil surface at all times for water, and wind erosion control, (ii) to conserve soil and water and (iii) to reduce energy use [26]. Some of the conservation tillage practices followed in hill ecosystems are discussed here.

4.3.2. In-Situ Residue Management. Low native soil nitrogen $(\mathrm{N})$ and very low phosphorus $(\mathrm{P})$ coupled with apathy of farmers towards use of fertilizer is the major constraints limiting the rice productivity in NEH Region of India. Productivity and nutrient recycling potential in rice (Oryza 
TABLE 8: Changes in SOC $\left(\mathrm{Mg} \mathrm{hm}^{-2}\right)$ over the years under various MPTs in humid tropics.

\begin{tabular}{lcccc}
\hline \multirow{2}{*}{ MPTs } & \multicolumn{4}{c}{ Years } \\
& 4 & 8 & 12 & 16 \\
\hline A. auriculiformis & 11.1 & 11.9 & 17.9 & 21.9 \\
M. alba & 9.9 & 9.9 & 9.9 & 15.9 \\
L. leucocephala & 11.5 & 11.5 & 12.8 & 16.7 \\
D. sissoo & 13.1 & 12.5 & 13.1 & 13.9 \\
G. maculate & 13.1 & 13.1 & 13.9 & 14.9 \\
A. indica & 10.9 & 10.9 & 14.7 & 28.6 \\
M. champaca & 13.9 & 13.7 & 13.9 & 16.9 \\
E. hybrid & 9.9 & 9.9 & 14.9 & 16.1 \\
T. grandis & 11.5 & 11.3 & 11.5 & 12.9 \\
G. arborea & 12.2 & 12.2 & 12.8 & 21.8 \\
S. saman & 10.6 & 11.3 & 11.3 & 13.9 \\
A. procera & 13.5 & 13.1 & 13.5 & 14.7 \\
Open space (Control) & 11.9 & 11.9 & 11.1 & 9.1 \\
\hline
\end{tabular}

Source: [24].

sativa L.) - vegetables cropping sequences under low input in-situ residue management under rainfed condition was evaluated on lowland situation at ICAR Research Complex for NEH Region, Umiam, Meghalaya. After harvesting of rice, five vegetable crops, viz., tomato, potato, frenchbean, cabbage, and carrot, were grown. No external input including fertilizer, pesticides, and so forth was applied except one hand weeding at 30 days after transplanting in case of rice. In case of vegetables, only one earthing up and intercultural operations were done as per the requirement of the crops. Only the economic parts of crops were harvested and left-out portion including weed residues were chopped and incorporated into the soil. A considerable amount of nutrients were recycled through in-situ weed biomass incorporation. The weed biomass ranged from $37.5 \mathrm{q} / \mathrm{ha}$ with rice-tomato to $50.6 \mathrm{q} /$ ha in rice-fallow. Highest amount of NPK recycling was recorded from rice-potato sequence. Soil fertility in terms of available NPK status analysed after 4 years was found stable in all the crop sequences except rice-cabbage, where it declined slightly. The soil biological properties like population of Rhizobium, bacteria, phosphorus solubilizing microorganisms, and earthworm activity all were found remarkably higher in experimental field compared to plots that are managed inorganically.

4.3.3. Incorporation of Jungle Grass. Long-term effects of different locally available grasses and weeds on soil hydrophysical properties and rice yield through a 5-year field experimentation under hilly ecosystem of Meghalaya depicted that incorporation of jungle grass (Ambrosia spp.), in puddled rice soil improved soil organic carbon (SOC) by $21.1 \%$, the stability of microaggregates, moisture retention capacity, and infiltration rate of the soil by $82.5,10$, and $31.3 \%$, respectively, and soil bulk density decreased by $12.6 \%$ [27]. Locally available jungle grasses are equally good as an organic amendment, which would also ease the problem of

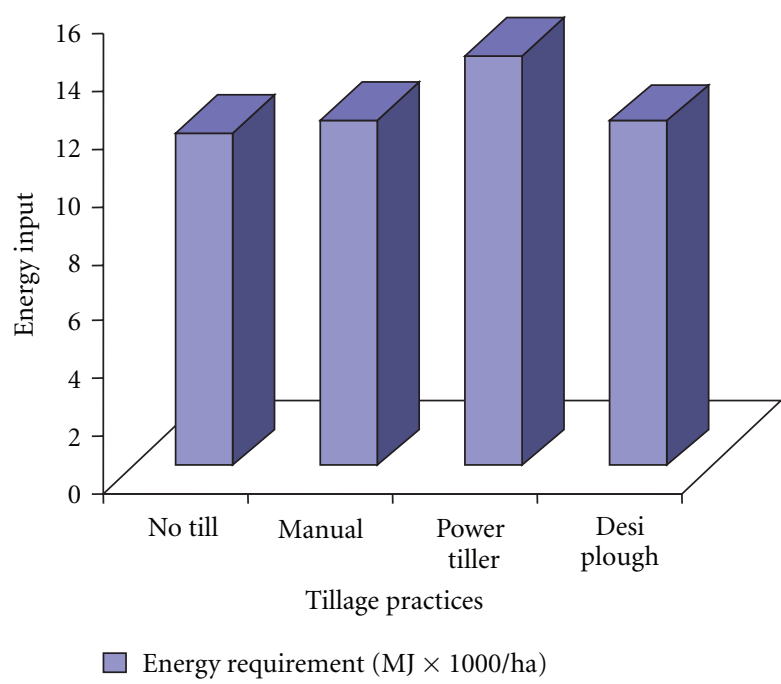

Figure 1: Energy requirement of different tillage practices. Source: [28].

disposal of these grasses during peak monsoon. Therefore, these organic sources may serve as alternative to farm yard manure (FYM) and have a dramatic effect on long-term productivity of rice.

4.3.4. Zero Tillage. Zero tillage in rice-based system improves physical properties of soil like soil structure, increase the relative proportion of biochannels, macropores, and decrease the susceptibility of crusting. It has been observed that the bulk density of soil decreased about $25 \%$, total porosity and soil aggregates increased by 29 and $32 \%$, respectively, over the conventional tillage practices (2-3 passes of powertiller/spade). It also increases the SOC content by $12.5 \%$, available $\mathrm{P}$ by $14.3 \%$, and $\mathrm{K}$ by $29.4 \%$ over conventional tillage. Zero tillage saved 20\% energy (Figure 1) and fertilizer needs as compared other conventional tillage methods by conserving soil and water [28] without jeopardizing the crop production (rice yield of $37 \mathrm{q} / \mathrm{ha}$ ). In other tillage practices like power-tilled, desiploughed, or manually weeding, the energy in terms of labour requirement was much higher.

Integrated Plant Nutrient Supply. Integrated use of balanced inorganic fertilizer in combination with lime and organic manure sustains a better soil health for achieving higher crop productivity under intensive cropping systems in hilly ecosystem of north eastern India. Study suggests that addition of NPK fertilizers along with organic manure, lime, and biofertilizers had increased SOC content, aggregate stability, moisture retention capacity, and infiltration rate of the soil while reducing bulk density. The SOC content under the treatment $100 \%$ NPK + lime + biofertilizer + FYM was significantly higher $(68.6 \%)$ than control plots [29].

Pastural Development. Resource conserving and environmental friendly production strategies are desirable for agrarian economies. Grass cover is the key factor in improving soil physicochemical health by assuring regular addition of 
organic matter, thus reducing surface runoff and soil erosion. Some promising perennial grasses like Setaria, Congosignal, Guinea, Napier, and Broom grass were tested for their effect on soil physicochemical properties. Study [30] revealed that continuous 15 years grass covers significantly increased the SOC, the highest SOC content with Setaria (2.24\%). Similarly, Soil microbial biomass carbon, soil aggregation, and infiltration rate under various grass covers were also high as compared to plots without grass covers.

Hedgerow Intercropping. As the trees have long gestation period, farmers may be reluctant to cultivate the trees mainly due to prevailing land tenure system in the region. However, cultivating various hedgerow species even in jhum field could be better option for them as these species have short gestation period. Hedgerows alone reduced soil loss by $94 \%$ and run-off by $78 \%$. When twigs and tender stem of hedge plants are used for mulch, it conserved $83 \%$ of the soil and $42 \%$ of rainfall. In a study conducted at Changki, Nagaland in $\mathrm{NEH}$ region, the soil loss was reduced by $22 \%$ with the incorporation of hedgerow species in the jhum fields compared to traditional jhum site (38.14t/ha/yr). Thus contour hedgerow technology provides an option for farming on the hill slopes on a sustainable basis. Growing of nitrogen fixing hedge species on the field bunds helps in fixation of atmospheric nitrogen and reduces the leaching losses of mineral nitrogen. Their vigorous root system mobilizes phosphorus, potassium, and other trace elements.

ICAR Research Complex for NEH Region has also screened various hedgerow species for plantation, and $\mathrm{Ca}$ janus cajan, Crotalaria tetragona, Desmodium rensonii, Flemingia macrophylla, Indigofera tinctoria, Tephrosia candida, and Gliricidia maculata have been found suitable for farming in Eastern Himalayas. Survival percentage of these species ranged from 60.0 to 80.0 over degraded sites. The total $\mathrm{N}$, $\mathrm{P}$, and $\mathrm{K}$ concentration in the foliage of hedgerow species ranged from $3.23-3.86 ; 0.32-0.81 ; 1.26-1.67 \%$, respectively. Total leaf biomass production on the dry weight basis after one year of growth was found to be highest in $C$. tetragona (22.98 q/ha) followed by G. maculata ( $20.75 \mathrm{q} / \mathrm{ha})$, I. tinctoria ( $16.99 \mathrm{q} / \mathrm{ha})$, and T. candida ( $15.30 \mathrm{q} / \mathrm{ha})$. Among the hedgerow species, $C$. tetragona enriched the soil fertility more efficiently as it accumulated higher amount of total $\mathrm{N}, \mathrm{P}$, and $\mathrm{K}(79.74,11.03$, and $37.46 \mathrm{~kg} / \mathrm{ha})$ through its leaf incorporation. The recycling of bases in litter of hedgerow could potentially counteract the acidification [31]. The incorporation of leaf biomass of $T$. candida improved the $\mathrm{pH}$ in acid soil by increasing 0.49 units from the initial level at surface soil. Thus, the biomass produced from hedgerows showed a favorable influence on soil acidity.

4.4. Organic Farming. Organic farming is primarily in operation in areas under shifting cultivation and traditional land use systems in north east India. Nearly $57.1 \%$ of total geographical area (TGA) in India is under the threat of land degradation mainly by water erosion. On an average, $37.1 \%$ of TGA in NE India is in degraded state. Fertilizer use in most of the states of the region is far below the national average. The use of $\mathrm{N}, \mathrm{P}$, and $\mathrm{K}$ through fertilizer in the region is only $13.37,11.12$, and $11.0 \%$ of the crop removal thus necessasiating the organic source of nutrition in the domain of soil health management. Organic sources if pooled together can supply $13.07 \mathrm{~kg} \mathrm{~N} / \mathrm{ha}, 7.18 \mathrm{~kg}$ phosphate/ha, and $7.34 \mathrm{~kg}$ potash/ha in NE India. The micronutrient supply from organic sources may be adequate. Substantial amount of potash can be obtained from crop residues if managed to add in soils. Biofertilizers in case of adequate supply can produce an increase (5-30\%) in yield. Vermicomposting of rural wastes holds a great promise in mitigating nutrient hunger of soils in NE India considering supply of composting earthworms and need based training in compost technology. Soil amelioration with the use of limestone deposit available in north east can be brought in use. Finally, watershed based technology with proper soil and water conservation measures can be an effective avenue to nurture soil health for sustainable organic food production.

\section{Epilogue}

Even today, Jhuming is considered as a major source of rural economy in north eastern part of India and will remain as important one as it is associated with socioeconomic and cultural systems of the people of this region. Because of this, degradation will continue in the years to come and may reach to the extent of out of control, if proper care is not taken right now. Therefore, to reduce all types of degradation level, a comprehensive forest policy is required as a long-term strategy in the region for sustainability and augmentation of food, fuel, fodder, and timer requirements. In this direction, agroforestry coupled with some sound resource conservation techniques needs to be strengthened for long-term sustainable production and environmental conservations in fragile ecosystem which will contribute to improved food security and income generation for resource poor farmers and protect the environments.

Integrated farming system (IFS) has emerged as a well accepted, single window, and sound strategy for harmonizing simultaneously jointmanagement of land, water, vegetation, livestock, and human resources, The IFS developed for hill areas could reduce the risk of soil degradation, produce the soils productive potential, and reduce the risks of environmental degradation. Besides, these interventions having a tree crop with a high quality of leaf litter and root binding ability reduce erodibility of rainfall/runoff and improve the physicochemical conditions. Attempt should also be made to manage soil health through addition of organic inputs in this region.

\section{References}

[1] W. H. Schlesinger, "Carbon sequestration in soils," Science, vol. 284, no. 5423, p. 2095, 1999.

[2] D. N. Borthakur, Agriculture of the North Eastern Region with Special Reference to Hill Agriculture, Beecee Prakashan, Guwahati, India, 1992.

[3] Anonymous, Wastelands Atlas of India, Ministry of Rural Development, Government of India and National Remote Sensing Agency, Hyderabad, India, 2000. 
[4] Anonymous, State of Forest Report, Forest Survey of India. Ministry of Environment and Forests, Government of India, 2001.

[5] S. C. Ram and P. S. Ramakrishnan, "Hydrology and soil fertility of degraded grasslands at Cherrapunji in North Eastern India," Environment Conservation, vol. 15, pp. 29-35, 1988.

[6] M. Kellman, K. Miyanishi, and P. Hiebert, "Nutrient retention by savanna ecosystems II. Retention after fire," Journal of Ecology, vol. 73, no. 3, pp. 953-962, 1985.

[7] I. F. Ahlgren and C. E. Ahlgren, "Effect of prescribed burning on soil microorganisms in a Minnesota jack pine forest," Ecology, vol. 46, no. 3, pp. 304-310, 1965.

[8] G. Griffith, "Fertility problems in Uganda," Technical Communication, Commonwealth Bureau of Soil Science, vol. 46, pp. 160-164, 1949.

[9] M. Ram and B. P. Singh, "Soil fertility management in farming systems," Lectures notes, off campus training on farming system, Aizawl, India, 1993.

[10] A. Singh and M. D. Singh, "Effect of various stages of shifting cultivation on soil erosion from steep hill slopes," Indian Forester, vol. 106, no. 2, pp. 115-121, 1981.

[11] D. Mandal, K. S. Dadhwal, O. P. S. Khola, and B. L. Dhyani, "Adjusted $\mathrm{T}$ values for conservation planning in Northwest Himalayas of India," Journal of Soil and Water Conservation, vol. 61, no. 6, pp. 391-397, 2006.

[12] U. C. Sharma, "Methods of selecting suitable land use system with reference to shifting cultivation in NEH region," Indian Journal of Soil Conservation, vol. 26, no. 3, pp. 234-238, 1998.

[13] N. P. Singh, O. P. Singh, and N. S. Jamir, Sustainable Agriculture Development Strategy for North Eastern Hill Region of India, Mittal, New Delhi, India, 1996, Edited by Shukla S. P. and Sharma N.

[14] B. P. Bhatt, "Agroforestry for sustainable mountain development in N.E.H. region," in Central Himalaya Environment and Development: Potentials, Actions and Challenges, M. S. S. Rawat, Ed., pp. 206-223, Transmedia Publisher, Uttaranchal, India, 2003.

[15] Umashankar, "Indigenous agroforestry tree species for conservation and rural livelihood," in Agroforestry in North East India: Opportunities and Challenges, B. P. Bhatt and K. M. Bujarbaruah, Eds., pp. 149-174, ICAR Research Complex for NEH Region, Umiam, Meghalaya, 2005.

[16] R. Saha, J. M. S. Tomar, and P. K. Ghosh, "Evaluation and selection of multipurpose tree for improving soil hydro-physical behaviour under hilly eco-system of north east India," Agroforestry Systems, vol. 69, no. 3, pp. 239-247, 2007.

[17] B. P. Singh and S. K. Dhyani, "Significance of jackfruit in restoration of soil fertility," Annual Report, ICAR Research Complex, Umiam, Meghalaya, 1995.

[18] B. Majumdar, K. Kumar, M. S. Venkatesh, Patiram, and Bhatt B. P., "Effect of different agroforestry systems on soil properties in acid Alfisols of Meghalaya," Journal Hill Research, vol. 17, no. 1, pp. 1-5, 2004.

[19] B. Majumdar, M. S. Venkatesh, K. K. Satapathy, K. Kumar, and Patiram, "Effect of alternative farming systems to shifting cultivation on soil fertility," Indian Journal of Agricultural Sciences, vol. 72, no. 2, pp. 122-124, 2002.

[20] R. Saha and V. K. Mishra, "Long-term effect of various land use systems on physical properties of silty clay loam soil of NE hills," Journal of the Indian Society of Soil Science, vol. 55, no. 2, pp. 112-118, 2007.

[21] K. K. Satapathy, "Runoff production on hill slopes under different land use systems," in Agroforestry in North East India: Opportunities and Challenges, B. P. Bhatt and K. M.
Bujarbaruah, Eds., pp. 451-459, ICAR Research Complex for NEH Region, Umiam, Meghalaya, 2005.

[22] R. Saha, V. K. Mishra, and J. M. S. Tomar, "Effect of agroforestry systems on erodibility and hydraulic properties of Alfisols in eastern Himalayan region," Indian Journal of Soil Conservation, vol. 33, pp. 251-253, 2005.

[23] R. Saha, P. K. Ghosh, V. K. Mishra, B. Majumdar, and J. M. S. Tomar, "Can agroforestry be a resource conservation tool to maintain soil health in the fragile ecosystem of north-east India?" Outlook on Agriculture, vol. 39, no. 3, pp. 191-196, 2010.

[24] M. Datta and N. P. Singh, "Growth characteristics of multipurpose tree species, crop productivity and soil properties in agroforestry systems under subtropical humid climate in India," Journal of Forestry Research, vol. 18, no. 4, pp. 261-270, 2007.

[25] S. L. Swamy, S. Puri, and A. K. Singh, "Growth, biomass, carbon storage and nutrient distribution in Gmelina arborea Roxb. Stands on red lateritic soils in central India," Bioresource Technology, vol. 90, no. 2, pp. 109-126, 2003.

[26] P. K. Ghosh, A. Das, R. Saha et al., "Conservation agriculture towards achieving food security in North East India," Current Science, vol. 99, no. 7, pp. 915-921, 2010.

[27] R. Saha and V. K. Mishra, "Effect of organic residue management on soil hydro-physical characteristics and rice yield in eastern Himalayan region, India," Journal of Sustainable Agriculture, vol. 33, no. 2, pp. 161-176, 2009.

[28] V. K. Mishra, R. Saha, and K. M. Bujarbaruah, "Zero tillage technique for transplanted rice in high rainfall eco-system," Scientific leaflet., ICAR Research Complex for NEH Region, Umiam, Meghlaya, 2005.

[29] R. Saha, V. K. Mishra, B. Majumdar, K. Laxminarayana, and P. K. Ghosh, "Effect of integrated nutrient management on soil physical properties and crop productivity under a Maize (Zea mays)-mustard (Brassica campestris) cropping sequence in acidic soils of Northeast India," Communications in Soil Science and Plant Analysis, vol. 41, no. 18, pp. 2187-2200, 2010.

[30] P. K. Ghosh, R. Saha, J. J. Gupta et al., "Long-term effect of pastures on soil quality in acid soil of north-east India," Australian Journal of Soil Research, vol. 47, no. 4, pp. 372-379, 2009.

[31] K. Laxminarayana, B. P. Bhatt, and R. Tulsi, "Soil fertility buildup through hedgerow intercropping in integrated farming system: a case study," in Agroforestry in North East India: Opportunities and Challenges, B. P. Bhatt and K. M. Bujarbaruah, Eds., pp. 495-506, ICAR Research Complex for NEH Region, Umiam, Meghalaya, 2005. 

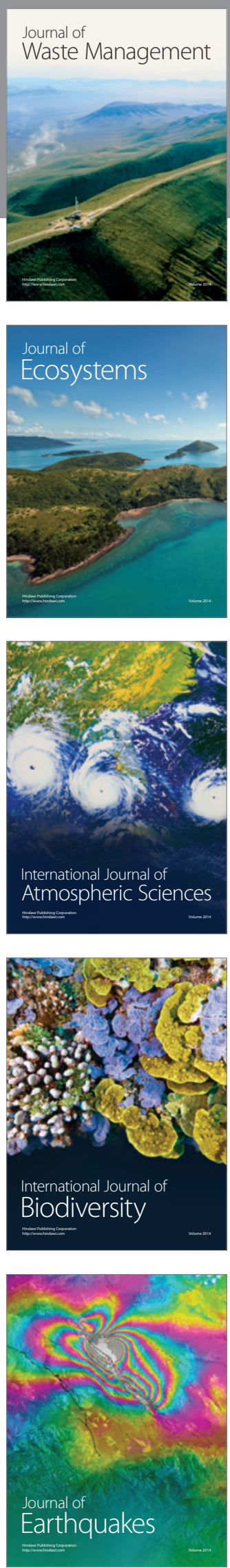
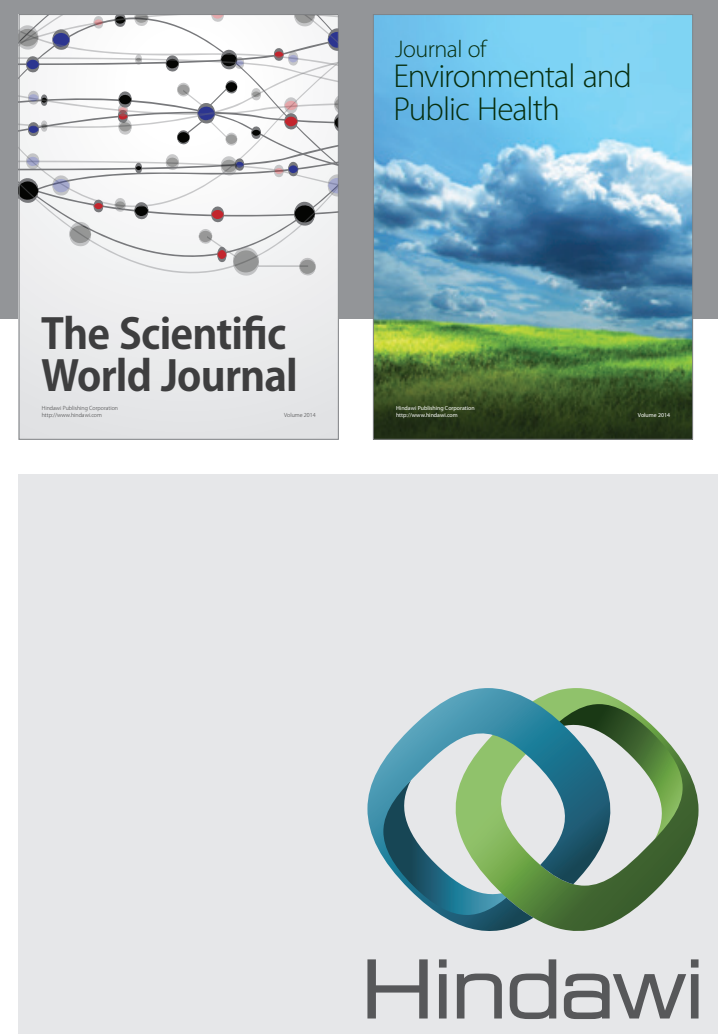

Submit your manuscripts at

http://www.hindawi.com
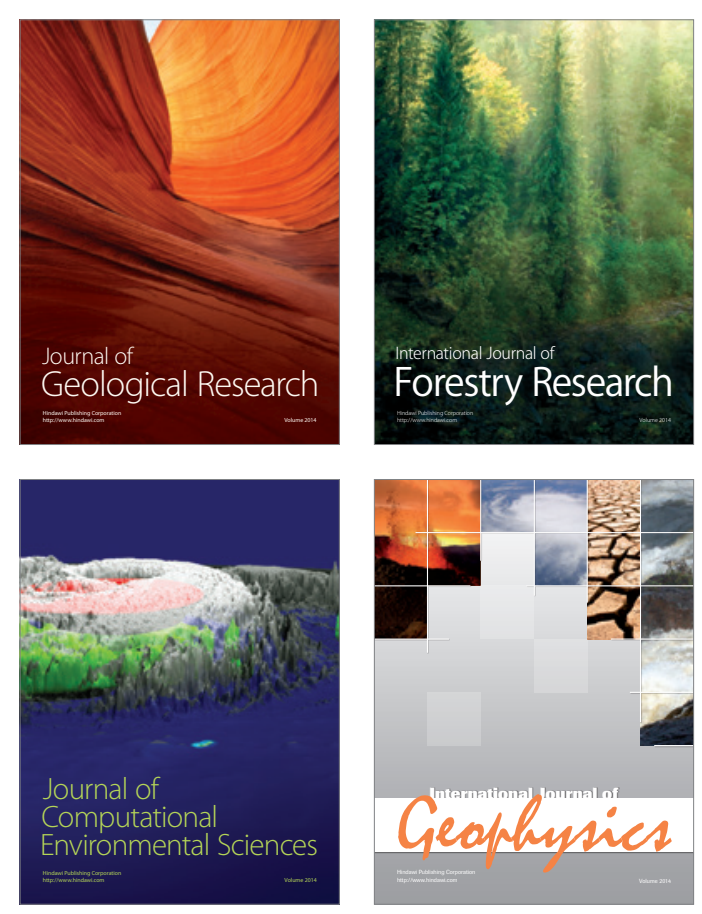
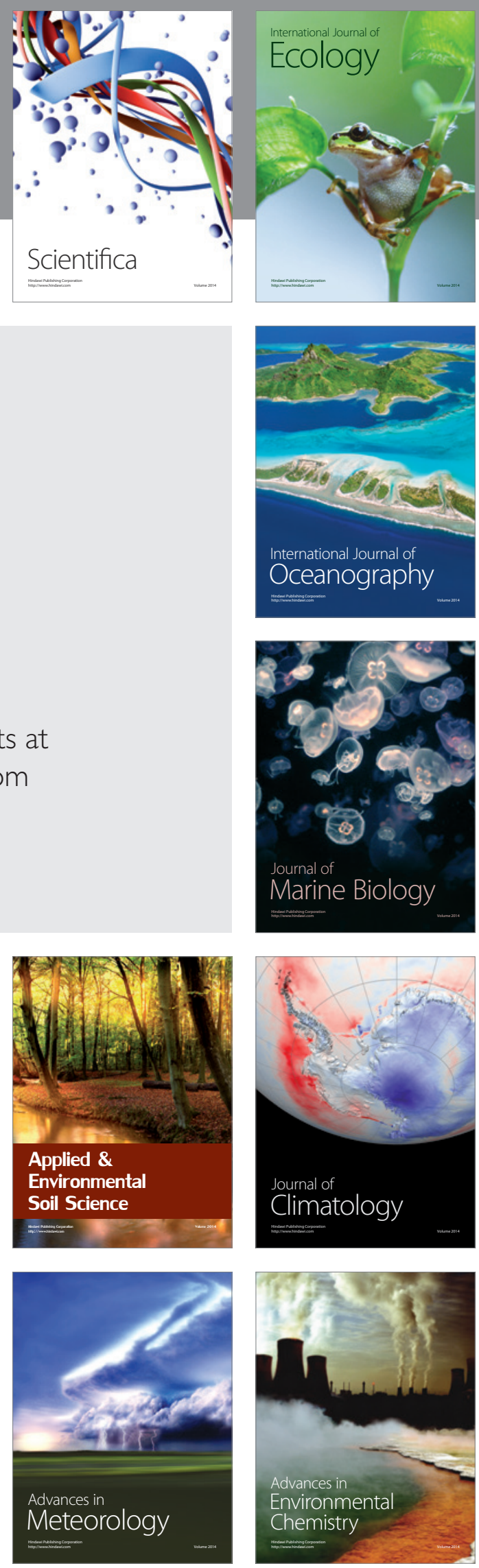